\title{
Dealing with Long-Term Deficits
}

\section{Citation}

Feldstein, Martin. 2016. “Dealing with Long-Term Deficits." American Economic Review 106 (5): 35-38. https://doi.org/10.1257/aer.p20161004.

\section{Permanent link}

http://nrs.harvard.edu/urn-3:HUL.InstRepos:41555792

\section{Terms of Use}

This article was downloaded from Harvard University's DASH repository, and is made available under the terms and conditions applicable to Open Access Policy Articles, as set forth at http:// nrs.harvard.edu/urn-3:HUL.InstRepos:dash.current.terms-of-use\#OAP

\section{Share Your Story}

The Harvard community has made this article openly available.

Please share how this access benefits you. Submit a story.

Accessibility 


\section{Dealing with Long Term Deficits}

\section{Martin Feldstein*}

Before discussing the challenge of reducing future deficits, I will comment briefly on the current conditions of the U.S. economy. Fortunately, the American economy is now in good shape. We are essentially at full employment with the overall unemployment rate at 5.0 percent and the unemployment rate among college graduates at a very low 2.5 percent. The near zero overall rate of inflation is distorted by the sharp decline in energy prices. The core CPI inflation rate that excludes the prices of energy and food has increased by 2.0 percent over the past 12 months.

Looking ahead, the growth of GDP in 2016 will be limited by the absence of excess capacity in the economy rather than by a lack of demand. Household spending will support real domestic demand growth of two percent or more because real earnings are rising at two percent, real house prices are increasing even faster, and employment prospects are good. The primary risk to the U.S. economy in the coming year is probably the mispricing of assets and the provision of high risk loans, both of which have resulted from excessive reaching for yield by investors and lenders because of the very low interest rates at all maturities that have prevailed in recent years.

But looking to the longer term, the most serious risk to the U.S. economy is the explosive growth of the national debt that will occur unless there are specific policy actions. The ratio of the federal government debt to the GDP has doubled in the past decade from a level of less than 40 percent that prevailed for many years before the recent recession to 75 percent of GDP now. With an annual deficit of about three percent and a growth raBefore te of nominal GDP of about 4 percent, the debt ratio could remain at about 75 percent for the next few years.

\footnotetext{
* Professor of Economics, Harvard University. Presented at the American Economic Association meeting, January 3, 2016. Forthcoming in the Papers and Proceedings of the American Economic Association, May 2016.
} 
But the Congressional Budget Office warns that with current policies the deficit share of GDP will soon start to increase, causing the ratio of debt to GDP to rise as well.

One important reason for the future deficit increase is that the normalizing of interest rates will increase the cost of the interest on the national debt. The CBO estimates that the interest on the national debt will rise from 1.2 percent of GDP in 2015 to 2.8 percent in 2025, raising the annual deficit by 1.6 percentage points

A second important reason for the rising level of the budget deficit is the increased cost of the transfer payments to middle class seniors. These are not the means tested programs for the poor but the much more expensive transfers in the Social Security and Medicare programs.

The CBO estimates that the cost of Social Security will rise from 4.9 percent of GDP now to 5.7 percent of GDP a decade from now and then to 6.2 percent of GDP by 2040 . The rising cost reflects not only the increased number of beneficiaries but also the higher real level of the benefits per retiree. The cost of Medicare will rise even more rapidly, propelled by the relative aging of the population and the greater use of services by the "old old" than by those under age 75, as well as by the changes in medical technology that provide opportunities to provide useful care at a higher cost.

Putting all of this together, the Congressional Budget Office (2015) projects that the deficit a decade from now will be 4.0 percent of GDP and the federal debt will be on its way to 100 percent of GDP by the year 2039. I suspect that even this disturbing forecast is too optimistic because a debt trajectory like that is likely to cause portfolio investors in the United States and elsewhere to conclude that the U.S. government has lost control of its fiscal policy. If that happens, interest rates on U.S. government bonds will rise faster, bringing with it an even larger deficit and a more rapid growth of the national debt.

Such a rise in the national debt is a serious problem for four reasons. (Feldstein, 2011) First, servicing the debt requires raising taxes and those taxes impose efficiency costs on the economy. Second, with more than half of the national debt held abroad, paying interest on that debt requires a lower real value for the 
dollar, reducing U.S. living standards by worsening our terms of trade. Third, a higher debt reduces the government's room to raise spending in case of a military problem or an economic downturn. Fourth, the higher debt crowds out private capital formation, reducing real incomes.

It is important therefore to reverse the upward path of the debt to GDP ratio. The good news is that this requires only a relatively small shift in the annual deficit to GDP ratio. If the future nominal growth rate of GDP is four percent, an annual deficit of four percent of GDP will cause the debt ratio to rise to 100 percent of GDP. But if the annual deficit is cut to two percent of GDP, the debt ratio will gradually decline to just 50 percent.

The ratio of debt to GDP can be reduced by a combination of increasing the future level of GDP and decreasing the size of the future government debt. A sustained increase in the future GDP can be achieved by changes in tax rules, in regulation, and in national programs of education and training. (Feldstein, 2014) Cutting high corporate tax rates and shifting to a territorial tax system would shift investment into corporations in the United States, raising real GDP. A wide range of environmental and other regulations currently depress real GDP, so that eliminating those regulations would raise future GDP. Improving the quality of education and of post-secondary school training would make the labor force more productive.

Reducing the future deficits requires cutting spending, raising taxes, or doing both. Although there is undoubtedly waste in both the defense and non-defense outlays, there is in reality little scope for significant reductions in spending on defense or on the annually appropriated nondefense programs. Defense spending is already projected to decline to just 2.6 percent of GDP in the coming decade, the lowest GDP share since before World War II, despite to increased military risks that the U.S. now faces. The annually appropriated nondefense programs are also projected to decline to just 2.5 percent of GDP, also the lowest GDP share in more than 50 years.

Reducing spending therefore requires slowing the growth of the middle class programs of Social Security and Medicare. I will focus my comments on the Social Security retiree benefits. Reducing the growth of Social Security outlays is not only a 
way to shrink future fiscal deficits but also a way to sustain the Social Security program itself since it will otherwise be necessary to reduce benefits dramatically when the balance of the Social Security trust fund reaches zero (Feldstein, 2005).

There are many ideas about how to reduce the growth rate of benefits. My own preferred approach would be to increase the age at which retirees receive the full level of benefits. That "full benefit age" is currently 67. The increase could be legislated to begin at some time in the future so that those who are now approaching age 67 would not be affected. Even after the age for full benefits is raised, individuals could continue to have the option of retiring earlier with benefits subject to a reduction that keeps the real actuarial present value of those benefits unchanged. Because average benefits are now projected to increase in future years, slowing their growth could still be consistent with a rising level of real benefits per retiree.

This approach to slowing the growth of total Social Security outlays is what Congress did back in 1983 when it faced the risk that the Social Security tax revenue would not be enough to pay projected benefits. Congress raised the age for full benefits from 65 to 67 , very gradually and with a delay, while also maintaining the option to receive actuarially reduced benefits at an earlier age.

In the three decades since 1983, average life expectancy at age 67 has increased by three years. I think it makes sense to increase the age for full benefits gradually by three years to age 70 and then automatically raise the age of full benefits in future years in line with increasing life expectancy.

Some economists object to this proposal because life expectancy has not increased as much for individuals with lower lifetime earnings. The proposal to increase the full benefit retirement age could be modified to take this into account. Since the Social Security Administration has data on each person's earnings history, the age for full retirement benefits could be adjusted to reflect each person's lifetime earnings, allowing those with lower earnings to receive full benefits sooner.

In addition to slowing the growth of Social Security benefits, the future budget deficits could be reduced by raising tax revenue. Fortunately, it is possible to increase tax revenue without exacerbating the adverse incentives that result from 
higher tax rates. Two alternative revenue strategies would actually have favorable incentive effects in addition to raising revenue: limiting tax expenditures and raising the cost of carbon in general or gasoline in particular.

Consider first the strategy of limiting tax expenditures, i.e., the forms of government spending achieved by tax rules rather than by explicit outlays. (Feldstein, et. al., 2011; Feldstein, 2016.)

For example, if I buy a Prius or other hybrid car, the government rewards me. It doesn't do this by sending me a check but it gives me a reduction in my tax liabilities. Similarly, if I install a solar panel at my home, the government rewards me with a tax reduction.

There are a large number of these forms of spending built into the tax code. A pernicious feature of these tax expenditures is that, unlike traditional government outlays, these features of the tax law do not have to go before Congress for annual review and reauthorization. It would be desirable for the Congress to review all of these individual tax expenditures and decide which ones we can continue to afford in the current budget situation.

There are of course several much bigger tax expenditures including the deduction for state and local tax payments, the deduction for mortgage interest, and the exclusion of employer payments for health insurance. It would obviously be politically very difficult to eliminate any of these popular tax expenditures. My preference is therefore to allow taxpayers to use all of them but to limit the total tax reduction that a taxpayer can achieve in this way.

I have studied a cap on the tax benefit from using these major tax expenditures equal to two percent of the individual's adjusted gross income. Such a cap would raise revenue equal to about one percent of GDP and would do so in a progressive way. It would also induce about two-thirds of individuals who currently itemize deductions to shift to the standard deduction. This would not only represent a substantial simplification in tax compliance but would also reduce the deadweight burden caused by excessive consumption of tax-deductible forms of spending. A similar reduction in current deadweight burdens would be achieved for those 
taxpayers who do not shift to the standard deduction but for whom the two percent cap creates a binding constraint on the amount of their deductions and exclusions.

One of the reasons that I like the idea of a limit on tax expenditures is that it should appeal to both Democrats and Republicans. Democrats insist that part of any deficit reduction plan must include increased tax revenue. Republicans want instead to reduce government spending. So limiting tax expenditures is a way of achieving both goals at the same time. I therefore work at explaining to my Republican friends that limiting tax expenditures is really a way to cut spending even though the effect of the deficit reduction shows up as an increase in revenue.

An alternative way of raising revenue without increasing marginal tax rates is to raise the tax on gasoline or to impose a broader tax on carbon consumption. The sharp fall in the price of oil and therefore of gasoline suggests that this is a politically opportune time for such a tax change. The fall in the price of oil from over $\$ 100$ a barrel to less than $\$ 40$ a barrel is equivalent to a decline of about $\$ 1.50$ per gallon of gasoline. The direct effect of increasing the existing federal gasoline tax by half this amount or 75 cents per gallon would be additional revenue of nearly $\$ 100$ billion a year or more than one-half percent of GDP.

A tax on gasoline would also have several advantages in addition to raising revenue. It would reduce the use of gasoline and the adverse environmental effects of gasoline consumption. It would also reduce driving and with it congestion and accidents.

In summary, we face a major problem of a rising future ratio of debt to GDP that, if allowed to continue, would have serious adverse consequences on the American economy. Fortunately, policy changes can increase the size of the future GDP and can shrink the future budget deficits. Relatively small reductions in future annual deficits could reverse the increasing ratio of national debt to GDP. Those reductions in the annual deficits could be achieved by slowing the growth of Social Security and Medicare or by raising revenue by limiting tax expenditures or increasing the tax on gasoline. The sooner these policies begin, the more favorable will be their effects.

December 2015 


\section{$\underline{\text { References }}$}

Congressional Budget Office, The Economic and Budget Outlook, 2015-25. Government Printing Office, 2015

Martin Feldstein, "Structural Reform of Social Security," Journal of Economic Perspectives, Vol. 19, Issue 2, pp.33-55 Spring 2005. $\overline{(2011)}$. 2014.

"How to Achieve Stronger US Growth," Journal of Policy Modeling, July/August "Raising Revenue by Limiting Tax Expenditures," Tax Policy and the Economy, vol 30 (2016)

Martin Feldstein, Dan Feenberg and Maya MacGuinneas, "Capping Individual Tax Expenditure Benefits”, in Tax Notes, May 2, 2011, p 505-509. 